\title{
The Therapeutic Effects of Agrimonia eupatoria L.
}

\section{Zoltán PALUCH ${ }^{1,2}$, Lilla BIRICZOVÁ ${ }^{1}$, Gergely PALLAG ${ }^{1}$, Emanuel Carvalheiro MARQUES ${ }^{1,4}$, Natália VARGOVÁ ${ }^{1,5}$, Eva KMONÍČKOVÁ ${ }^{1,3}$}

${ }^{1}$ Department of Pharmacology, Second Faculty of Medicine, Prague, Charles University, Czech Republic, ${ }^{2}$ St. John Nepomucene Neumann Institute, Př́bram, Czech Republic; St. Elisabeth University of Health Care and Social Work, Bratislava, Slovak Republic, ${ }^{3}$ Department of Pharmacology and Toxicology, Faculty of Medicine in Pilsen, Charles University, Plzeň, Czech Republic, ${ }^{4}$ Department of Dermatovenerology, Faculty Hospital Královské Vinohrady, Third Faculty of Medicine, Charles University, Czech Republic, ${ }^{5}$ Department of Dermatovenerology, Bulovka Hospital, Second Faculty of Medicine, Charles University, Czech Republic

Received December 10, 2020

Accepted December 17, 2020

\section{Summary}

Agrimonia eupatoria L. is an herb of the Rosaceae family, widely used in traditional (folk) medicine for its beneficial effects. Its water extracts (infusions and decoctions) are used in the treatment of airway and urinary system diseases, digestive tract diseases, and chronic wounds. Phytochemical analyses of Agrimonia eupatoria L. identified a variety of bioactive compounds including tannins, flavonoids, phenolic acids, triterpenoids and volatile oils possessing antioxidant, immunomodulatory and antimicrobial activities. The authors review the available literature sources examining and discussing the therapeutic and pharmacological effects of Agrimonia eupatoria L. at the molecular level in vitro and in vivo.

\section{Key words}

Agrimony • Antioxidant • Immunomodulatory • Antimicrobial • Therapeutic effect

\section{Corresponding author}

Z. Paluch, Department of Pharmacology, Second Faculty of Medicine, Charles University, Plzeňská 311, 15000 Praha 5, Czech Republic. E-mail: Paluch.Z@seznam.cz

\section{Agrimony in traditional medicine}

Common agrimony (Agrimonia eupatoria L.) (also church steeples, stickwort, or liverwort, among other names) is a perennial herbaceous plant of the Rosaceae family with small yellow star-shaped flowers, a short rhizome and a hard, hairy stem inhabiting pasture lands across Europe. Written accounts of the beneficial effects of agrimony date back as far as the 4th to 5th centuries; the herb was also mentioned in the Old English Herbarium from the 10th century (Cameron 2006, Voights 1979, Watkins et al. 2012).

Agrimonia eupatoria L. has long been used in traditional medicine to treat:

- lung inflammation

- diarrhea

- liver diseases

- cholecystitis, cholestasis

- intestinal or bladder atony

- pyelonephritis

- bleeding disorders

- $\quad$ skin defects

- inflammatory conditions of the oral mucosa.

Young stems of agrimony, its leaves and flowers were used to prepare (by isolating the flavonoid quercitrin) a yellow pigment and to increase the storage stability of beer (Kresánek and Krejča 1977).

Indications linked to references and documents published by regulatory authorities:

- relief of diarrhea (EMA 2015, Opletal and Skřivanová 2010), 
- relief of minor inflammations of the mouth and throat (Bradley 1992, ESCOP 2005),

- relief of skin inflammations, promotion of wound healing (EMA 2015, Ghaima 2013, Jahodáŕ 2010).

\section{Methods}

Relevant studies were identified using PubMed, Google Scholar and Science Direct. Reference lists of retrieved articles were also reviewed. The most relevant and up-to-date information was incorporated.

\section{Relevance of agrimony in current therapeutic use}

\section{Agrimony in European documents}

In a separate article, the European Medicine Agency (EMA) refers to agrimony as a plant with timetested use and effects - though not adequately validated in clinical trials yet - and said to possess antimicrobial activity and improve digestion (EMA 2015, Opletal and Skřivanová 2010).

Infusions made from agrimony green tops (leaves) are taken internally by adults for their antidiarrheal effects (astringent action) in diarrheal diseases or as a gargle in oral cavity inflammation and pharyngitis (sore throat) (Bradley 1992, ESCOP 2005). Agrimony has been reported to exert antimicrobial actions and improve digestion (Opletal and Skřivanová 2010). Infusions are also recommended in inflammation of the kidney (pyelonephritis) and inflammation of the gallbladder (cholecystitis) as well as cholestasis (Jahodář 2010). Alternatively, agrimony applied in the form of compresses or added to ointments is already a common type of topical therapy that has been found to be helpful in treating different skin conditions, namely chronic eczema, purulent wound and psoriasis (EMA 2015, Jahodář 2010). Furthermore, it speeds up wound healing and exerts hemostatic effects (Jahodáŕ 2010).

Generic drugs containing agrimony green tops (aerial parts) are available in liquid dosage forms to be applied either to the skin or used as bath additives. In documents published by EMA, the herb can be used to prepare ethanol extracts and water infusions. The former are available as tinctures (ratio of herbal substance to extraction solvent $1: 5$, extraction solvent, $45 \%$ ethanol $(\mathrm{V} / \mathrm{V})$ ) or water extracts (DER 1:1), extraction solvent, $25 \%$ ethanol (V/V) (EMA 2015). Water infusions are taken internally as teas and applied externally as gargles, compresses and baths. The infusions for internal use are prepared by pouring $250 \mathrm{ml}$ of boiling water on $1.5-4 \mathrm{~g}$ of the drug to be drunk twice or three times a day; with extracts, the amounts are $1-3 \mathrm{ml}$ and, with tinctures, $1-4 \mathrm{ml}$ to be taken three times per day. To prepare the infusion as a gargle, the dried herb is mixed with water at a 1:1 ratio. To treat superficial skin defects, compresses are applied, and baths taken twice a day. The herbal solutions for topical application are prepared by pouring $250 \mathrm{ml}$ of boiling water on 3-10 $\mathrm{g}$ of the dried drug. The effect of topical application to reduce inflammation or treatment of minor superficial wound is assessed after one-week therapy (EMA 2015). No data are available about the effect of agrimony-based remedies in children below 12 years of age, and in pregnant and breastfeeding women (EMA 2015).

Taken together, more scientific data are needed to explain the favorable traditional effects of Agrimonia eupatoria L. Of note, closely related to the species are A. pilosa Ledeb. a plant traditionally grown in Japan and China (Park et al. 2020), and A. procera Wallr. (Granica et al. 2015) inhabiting various parts of the world and currently being intensively studied for their promising biological activities.

\section{Antibacterial effects}

Agrimonia eupatoria $\mathrm{L}$. has been shown to have bactericidal action, in particular against Staphylococcus aureus in infected wounds (Watkins et al. 2012). Although wound colonization is most often polymicrobial, Staphylococcus aureus still seems to be among the most if not the most frequent causative agent of wound infections. It is therefore not surprising that Agrimonia eupatoria L. is broadly used in minor superficial wound healing. Wound healing is a complex multifactorial process. Quick wound healing depends both on the therapy used and on the patient (age, sex, tissue oxygenation, stress, hormones, diabetes, obesity, medications, alcoholism smoking, nutrition and infection) (Guo and DiPietro 2010). The presence of bacteria in wounds is not necessarily a disadvantage: to a certain degree, so called sub-infective, bacteria appears to increase neutrophil, monocyte and macrophage infiltration, raise prostaglandin $\mathrm{E}$ levels, boost collagen formation and promote granulation tissue formation. However, if a wound becomes locally infected or critically colonized, it will heal poorly: while chemotaxis becomes reduced due to high complement protein consumption whereas endotoxins, cytotoxic enzymes and 
free oxygen radicals increase tissue damage, release of vasoconstrictive metabolites induces localized thrombosis, dermal proteins are digested, fibroblast production decreases further interfering with collagen production (Edwards and Harding 2004). In clinical practice, topical agrimony is recommended to be applied to wounds for at least one week before the first assessment (EMA 2015).

Its antibacterial action against Staphylococcus aureus could also help explain its beneficial effect in the treatment of psoriasis and eczemas, especially atopic eczema. This highly prevalent condition (affecting up to $20 \%$ of children worldwide) is characterized by abnormal microbial colonization with pathogenic organisms such as Staphylococcus aureus or Malassezia furfur. The latest European guidelines recommend patients to take baths with bacterial growth inhibiting formulas such as sodium hypochlorite. Topical compounds with antimicrobial actions have also been suggested as effective, especially in cases of superinfection (Ring et al. 2012).

A meta-analysis published in 2017 confirmed that psoriatic lesions also seem to be at increased risk for staphylococcal colonization compared with healthy individuals ( $\mathrm{Ng}$ et al. 2017); in addition, an association between staphylococcal colonization and PASI (Psoriasis Area Severity Index) scores has been reported (Okubo et al. 2002, Tomi et al. 2005).

Root extracts have been found to have antimicrobial action against the Bacillus subtilis and Escherichia coli strains (Watkins et al. 2012). The effect of ethanolic agrimony extracts against Escherichia coli was superior to that of water agrimony extracts and was shown to have mild inhibitory activity against the Pseudomonas aeruginosa and Staphylococcus aureus strains (Ghaima 2013). Other studies have reported that the inhibitory activity of an agrimony extract was the most effective against Gram-positive bacteria (Muruzović et al. 2016). Regarding Gram-negative bacteria, and Escherichia coli in particular, the additive effect of Agrimonia eupatoria L. may be an advantage when combined with antibiotics, which act synergistically and are effective against resistant strains (Muruzović et al. 2017). The herb's extracts are employed in the management of diarrhea. Experimental results reported by Komiazyk et al. suggested that an extract inhibited the binding of Vibrio cholerae to fibroblast cells through ganglioside GM1 receptor immobilization in the cell membrane (Komiazyk et al. 2019).
A significant antimicrobial effect of Agrimonia eupatoria was shown against Helicobacter pylori underlining the role of this herb as a potential supplement besides the currently used antibiotic treatments (Cardoso et al. 2018, Cwikla et al. 2010).

\section{Antiviral effects}

The antiviral activity of agrimony has been documented in several recent studies. An ethanolic extract of Agrimonia eupatoria L. exhibited an inhibitory effect on mengovirus, also known as Columbia SK virus, which belongs to the genus Cardiovirus and its genome is formed by a single-stranded positive-sense RNA molecule. The antiviral effect was also confirmed in negative-sense RNA viruses. Water and ethanolic extracts of Agrimonia pilosa Ledeb., an herb of the same genus, were tested against human influenza viruses in in vitro and in ovo experiments (Shin et al. 2010). Specifically, the plant's antiviral effect was confirmed for H1N1 influenza A virus (Spanish flu in 1918), H3N2 influenza A virus (Hong Kong flu in 1968) and for influenza virus B. Antiviral activity was also found against the avian strain of H9N2 subtype of influenza A virus. Severe acute respiratory syndrome coronavirus 2 (SARS-CoV-2) belongs to the group of RNA-related viruses. However, no scientific information is available regarding the effect of agrimony on SARS-CoV-2. To date, several large studies examining natural compounds and their potential antiviral activity for coronavirus disease-19 (COVID-19) have been published based on molecular docking or other high throughput screening methods (Tripathi et al. 2020). One reason for the absence of agrimony in these studies can be the still poor knowledge about its individual compounds and appropriate cellular pathways resulting in specific pharmacological effects or low quality of pharmaceutical preparations.

The Agrimonia species have been reported to possess antihepatitis activities. Aqueous extracts prepared from the aerial parts (stems and leaves) of Agrimonia eupatoria L. and A. pilosa Lebed. inhibited hepatitis surface antigen (HBsAg) secretion (Kwon et al. 2019). The inhibitory effect of the extracts against hepatitis B virus (HBV) (DNA virus) was measured in HepG2.2.15 cells and was found to be temperature-dependent, with the optimal temperature for substances heated in water to $60{ }^{\circ} \mathrm{C}$ (Kwon et al. 2005). In the case of hepatitis $\mathrm{C}$ virus ( $\mathrm{HCV})$, a single-stranded RNA virus, an antiviral action was documented with A. pilosa Ledeb. (Kwon et al. 2019). The importance of the study lies in the 
identification of several metabolites in an ethanolic extract and their evaluation for anti-HCV activities. The following compounds have been found to inhibit the expression of the HCV core 1b NS5A proteins in Huh7.5 cells: hyperin, luteolin, astragalin, afzelin, nicotiflorin, tiliroside, apigenin, procyanidin B2, dihydroquercetin, coumarin, rutin, quercetin, apigenin-7-O-glucuronide and baicalin.

\section{Anti-inflammatory and immunodulatory effects}

Nitric oxide plays a regulatory role in the development of inflammation. At low concentrations, NO acts protectively. As regards the physiological responses, the key players include constitutive NO production through enzymes of endothelial nitric oxide synthase (eNOS) involved in vascular regulation, and neuronal NOS (nNOS) involved in synaptic plasticity control, smooth muscle relaxation, blood pressure control and vasodilation in the central nervous system (CNS). eNOS has been shown to possess antioxidant and antiproliferative effects (Guzik et al. 2003). As a response to pathogen infection, inducible nitric oxide synthase (iNOS) expression is induced in macrophages resulting in increased NO synthesis and further activation of inflammatory responses. In the early stage of a bacterial infection, Agrimonia procera Wallr. stimulated the defense response by upregulating cytokine production in pigs (Gräber et al. 2018). Alcohol (butanol and methanol) extracts of Agrimonia pilosa Ledeb. have been shown to significantly suppress iNOS and, consequently, NO production without affecting COX-2 (Jung et al. 2010). On the other hand, high NO and nitrogen radical levels are toxic promoting oxidative stress and inducing apoptosis. Agrimonia eupatoria L. extracts significantly reduced macrophage-produced NO levels in murine cell line macrophages (RAW 264.7) without adversely affecting cell viability. Of note, toxicities of extracts measured by 3-(4,5-dimethylthiazol-2-yl)-2,5-diphenyltetrazolium bromide (MTT) assay in vitro were found $770 \mu \mathrm{g} / \mathrm{ml}$ for a water extract and $276 \mu \mathrm{g} / \mathrm{ml}$ for a polyphenol-rich extract, while NO reduction was observed at concentrations of 382 and $138 \mu \mathrm{g} / \mathrm{ml}$, respectively. The anti-inflammatory and analgesic effects of water agrimony extracts devoid of a toxic effect were also documented under in vivo conditions. Carrageenaninduced rat paw edema in rats was significantly reduced by administration of aqueous and polyphenol-rich extracts. The effect was comparable to that of diclofenac sodium, a standard anti-inflammatory drug (Santos et al. 2017). Ethanolic extracts of Agrimonia pilosa Ledeb., an herb of the same genus, was shown to have antiinflammatory and anti-allergic activities inhibiting inflammatory cytokine (IL-1 $\beta$, IL-4, IL-6) and interferon$\beta$ (INF- $\beta$ ) production in induced RAW 246.7 cells (Kim et al. 2012). Moreover, an ethanolic extract of Agrimonia pilosa Ledeb. was found to inhibit $\mathrm{NO}$ and $\mathrm{PGE}_{2}$ production by downregulating iNOS and COX-2 expression. In vitro studies confirmed that administration of Agrimonia eupatoria L. extracts decreased the levels of tumor necrotic factor- $\alpha$ (TNF- $\alpha$ ), IL- $1 \beta$ and IL- 6 in murine microglial lines (Bae et al. 2010). In a study of Ivanova et al., regular consumption of agrimony tea for 30 days resulted in a reduction of the pro-inflammatory cytokine IL-6 in healthy volunteers (Ivanova et al. 2013).

\section{Antioxidant effects}

The antioxidant activity of Agrimonia eupatoria L. extracts exhibited a significant ability to neutralize the 2,2-diphenyl-1-picrylhydrazyl (DPPH), hydroxyl and superoxide anion radicals (Correia et al. 2007, Gurita (Ciobotaru) et al. 2018, Ivanova et al. 2001, Muruzović et al. 2016, Santos et al. 2017). The polarity of solvents used in the process of extraction affects the radical scavenging capacity with generally polar solvents being more potent (Venskutonis et al. 2007). A methanol extract of Agrimonia eupatoria L. was shown to have the highest antioxidant capacity among all herbs of the genus Agrimonia reflecting its highest bioflavonoid content (Kubínová et al. 2012). In the study of Ivanova et al., agrimony tea consumption $(1 \mathrm{~g} / 200 \mathrm{ml}$ twice a day) for 30 days significantly increased total antioxidant capacity of human blood plasma (Ivanova et al. 2013). Administration of an Agrimonia procera Wallr. extract to the roundworm (Caenorhabditis elegans) significantly reduced the magnitude of oxidative stress in these animals. Higher extract concentrations $(100$ and $200 \mu \mathrm{g} / \mathrm{ml}$ ) extended the roundworm's mean lifespan, presumably related to forkhead transcription factor DAF16 activation (mammalian FoxO orthologue) (Saier et al. 2018). In a study of Tupec and colleagues, the high antioxidant activity of an Agrimonia eupatoria extract correlated with the content of total phenolic compounds (Tupec et al. 2017).

\section{Analgesic effects}

Behavioral tests in rats documented an antinociceptive effect of Agrimonia eupatoria L. extracts 
$(200 \mathrm{mg} / \mathrm{kg})$ in a cisplatin-induced neuropathic rat model, although the mechanism of action has not been conclusively established to date (Lee and Rhee 2016). Administration of the same dose $(200 \mathrm{mg} / \mathrm{kg})$ of an Agrimonia pilosa Ledeb. extract to mice was also found to produce an antinociceptive action (Park et al. 2012). Administration of Agrimonia eupatoria L. and Agrimonia pilosa Ledeb. extracts did not shorten the pain response in the hot plate test in rats suggesting that the extracts do not act centrally. A significant reduction in foot swelling and decreased paw licking time suggest peripheral analgesic effects of the extracts (Santos et al. 2017).

\section{Phototherapic effects}

Grieve referred to Agrimonia eupatoria L. as a photosensitive plant (Grieve 1931). While photosensitivity can be a source of possible skin adverse reactions (phototoxicity, photoallergy, phytophotodermatitis, photoaging, skin cancers) (Jain et al. 2011), photosensitizing agents are often used in the field of dermatology. Vitiligo, psoriasis and mycosis fungoides are conditions that are often treated by combining ultraviolet A-rays (UVA) or B-rays (UVB) with photosensitizing agents (Asim et al. 2013). The basic mechanisms of action behind phototherapy include DNA synthesis suppression, reduction of Langerhans cells, T lymphocytes and mast cells as well as cytokine and prostaglandin stimulation - these induce immune suppression, alterations in cytokine expression and cell cycle arrest (Bulat et al. 2011). Such actions, stimulated by the photosensitizing potential of Agrimonia, might help explain its therapeutic effect in inflammatory conditions such as eczema and psoriasis.

\section{Hypotensive effects}

Extracts (10-20\%) made of the underground part of Agrimonia eupatoria L. were administered intravenously to anesthetized cats. Doses ranging between 0.25 and $1 \mathrm{ml} / \mathrm{kg}$ were found to have a hypotensive effect with more than a $40 \%$ decrease in blood pressure within 20 minutes of administration (Petkov 1979).

\section{Diuretic activity and uricolytic effects}

It was demonstrated that in rats, distilled water consumption resulted in loss of electrolytes via the kidneys. Administration of infusions at a concentration of $20 \mathrm{ml} / \mathrm{kg}$ and decoctions of Agrimonia eupatoria L. extracts at doses of 1,2 or $3 \mathrm{~g} / \mathrm{kg}$ with distilled water prevented losses of electrolytes, and $\mathrm{K}^{+}$ions in particular (Giachetti et al. 1989).

\section{Antidiabetic effects}

In a study using streptozotocin (STZ)-induced diabetic mice, agrimony decreased plasma glucose levels in these experimental animals (reducing hyperglycemia) and, generally, reduced polydipsia (Swanston-Flatt et al. 1990). Drinking of an agrimony decoction supplemented to potable water $(2.5 \mathrm{~g} / \mathrm{l})$ in mice for 12 days resulted in decreased water and food intake and a significant decrease in hyperglycemia in STZ-induced diabetes. Likewise, administration of a water extract to the rat BRIN-BD11 pancreatic B-cell line had antidiabetic effects, with increased glucose uptake, glycogenesis, carbon dioxide $\left(\mathrm{CO}_{2}\right)$ production and lactate output. Unlike direct dried herb administration, agrimony decoctions at concentrations of $0.25-10 \mathrm{mg} / \mathrm{ml}$ stimulated insulin secretion without an adverse effect on BRINBD11 pancreatic cell viability (Gray and Flatt 1998, Swanston-Flatt et al. 1990). Of all species of the genus Agrimonia, Agrimonia eupatoria L. - due to its highest flavonoid content - inhibited most significantly $\alpha$-glucosidase cleaving poly- and oligosaccharides to glucose, a process to be potentially employed in the treatment and management of diabetes (Kubínová et al. 2012, Kuczmannová et al. 2016). In an in vitro model, a water agrimony extract (decoction) was shown to inhibit glucose diffusion, a finding that suggested reduced rates of glucose absorption (Gallagher et al. 2003). In diabetic patients, hyperglycemia causes endothelial damage and deteriorates aortic elasticity. An Agrimonia eupatoria L. extract was reported to have significantly improved aortic relaxation (Kuczmannová et al. 2016). Diabetes combined with obesity poses a major health challenge associated as it is with increased expression of pro-inflammatory cytokines in adipose tissue and the liver and development of insulin resistance. In the mouse, a water Agrimonia pilosa Ledeb. extract alleviated metabolic syndrome symptoms while increasing the levels of adiponectin, an anti-inflammatory protein produced in adipose tissue (Jang et al. 2017).

\section{Hepatoprotective effects}

Elevated levels of alanine transaminase indicate damage to hepatic cells. In a randomized, double-blind, placebo-controlled study, twice-daily administration of capsules containing powdered Agrimonia eupatoria L. to 
subjects diagnosed with moderately elevated alanine transaminase levels for 8 weeks $(160 \mathrm{mg} / \mathrm{den})$ markedly decreased serum alanine transaminase, aspartate transaminase and triglyceride levels. Generally, Agrimonia eupatoria L. exerted a hepatoprotective action, improved lipid metabolism markers while having no adverse effects (Cho et al. 2018). Ethanolic extract administration to the rat caused liver damage at both macroscopic and microscopic levels upregulating toll-like receptor-4 (TLR-4), myeloid differentiation factor 88 (MyD88), iNOS, COX-2, and nuclear factor- $\mathrm{kB}$ (NF-kB) as well as causing liver steatosis and parenchymal inflammation with increased neutrophil infiltration and IL-6 and TNF- $\alpha$ cytokine production. Two-month administration of an Agrimonia eupatoria L. decoction was reported to be associated with a protective effect on the liver parenchyma, to alleviate the adverse effects of alcohol and to reduce the extent of steatosis and inflammation (Yoon et al. 2012).

\section{Anticancer effects}

Both water and methanol Agrimonia eupatoria L. extracts showed inhibitory activity on tumor (rhabdomyosarcoma [RD] and HeLa) cell lines, with the activity depending on the concentration $(12,24,48$ and $96 \mu \mathrm{g} / \mathrm{ml})$ and incubation period $(12,24$ and $48 \mathrm{~h}$ ) in vitro. No effect of the extracts was seen on normal cells (mouse embryonic fibroblasts, MEF) (Ad'hiah et al. 2013). Application of an Agrimonia pilosa Ledeb. extract $(50-400 \mu \mathrm{g} / \mathrm{ml})$ on liver cancer Hep G2 cell lines for 24 hours decreased anti-apoptotic B-cell lymphoma protein (Bcl-2, Bcl-XL) expression, induced myeloid leukemia cell differentiation protein (Mcl-1) and activated the caspase-induced apoptotic pathway (caspases 3 and 9) (Nho et al. 2011). Inhibition of antiapoptotic protein expression and enhanced pro-apoptotic protein expression were also observed in the human osteosarcoma U2-OS cell line. The extract's antitumor effect was confirmed in the BALB/c mouse (Huang et al. 2018). In vitro, conjugates of silver nanoparticles and an agrimony extract targeted at tumor cells inhibited the growth of A549 adenocarcinoma cells. The cytostatic effect of a combination of silver nanoparticles with agrimony was shown to be five times higher that of silver nanoparticles alone (Qu et al. 2014).

\section{Effect on wound healing}

According to a study of Ghaima (2013), topical application of an ethanolic (10\%) Agrimonia eupatoria
L. extract ointment shortened wound healing time to $10-16$ days, and its water (10\%) extract to 12 days in rats. Topical application of a water Agrimonia pilosa Ledeb. extract was found to improve epidermal permeability and maintain skin barrier function in mice. A water Agrimonia pilosa Ledeb. extract exhibited agonism to the transient receptor potential vanilloid 3 (TRPV3) cation channel in keratinocytes (Nam et al. 2017). While its function is primarily thermosensitive, TRPV3 plays a role in keratinocyte proliferation and differentiation as well as in stratum corneum formation (Cheng et al. 2010), hair follicle growth in the mouse (Imura et al. 2007) and maintenance of skin barrier function (Blaydon and Kelsell 2014). Upon activation, TRPV3 stimulates $\mathrm{Ca}^{2+}$ release, TNF- $\alpha$ production and epidermal growth factor receptor (EGFR) activation. The EGFR and TRPV3 subsequently form a signaling complex with eventual TRPV3 sensitization (Cheng et al. 2010). Agrimony's photosensitizing action might also contribute to wound healing by increasing the wound/ulcer bed sensitivity to ultraviolet radiation. Ultraviolet exposure induces cellular proliferation in the stratum corneum - this is a protective mechanism of the skin to fight further sunlight damage. UVC has been reported to induce fibronectin release, which promotes cell migration and wound contraction (Gupta et al. 2013).

\section{Phytoestrogen effects}

Agrimonia pilosa Ledeb. extracts were shown to act agonistically on estrogen receptors in MCF-7 breast cancer cells (in vitro) and to upregulate estrogenresponsive genes. Based on these findings, use of the extract is being considered to alleviate post-menopausal symptoms in women (Lee et al. 2012).

\section{Anti-atherosclerotic effects}

Thirty-day consumption of agrimony tea $(1 \mathrm{~g} / 200 \mathrm{ml}$ twice a day) was reported to have significantly decreased high-density lipoprotein (HDL) cholesterol levels in healthy volunteers (Ivanova et al. 2013).

\section{Antithrombotic effects}

A hexane extract of Agrimonia eupatoria L. $(500 \mu \mathrm{g} / \mathrm{ml})$ was shown to prevent thrombus formation. A polyphenolic-polysaccharide complex of Agrimonia eupatoria L. acted on the heparin cofactor II (HC II) to inhibit thrombin (Tsigoris-Maniecka et al. 2019). The herb's anticoagulant effect occurred at concentrations as 
low as $80 \mu \mathrm{g} / \mathrm{ml}$. Its water extract enhanced factor VII activity while decreasing factor VIII, IX and XI activity and inhibiting the intrinsic pathway (Fei et al. 2017).

\section{Neuroprotective effects}

A beneficial effect of Agrimonia pilosa Ledeb. was reported in the treatment of neurodegenerative diseases, dementia and Alzheimer's disease (Jung and Park 2007). In the rat, supplementation of the herb's water extract $(2 \%)$ to food prevented $\beta$-amyloid accumulation in the hippocampus (Park et al. 2017). Administration of a water Agrimonia pilosa Ledeb. extract appreciably mitigated the impact of ischemic brain damage, improved neurological function and $\mathrm{Na}^{+} / \mathrm{K}^{+}$ATPase activity as well as neuronal energy metabolism (Zhu et al. 2017). Interesting data were brought by Kubínová et al. (Kubínová et al. 2016). The authors investigated anticholinesterase activity of aqueous extracts from five species of the genus Agrimonia. They confirmed inhibition of cholinesterase enzyme in all the extracts at tested concentrations of $100 \mu \mathrm{g} / \mathrm{ml}$, with the best results obtained for A. pilosa Ledeb. In an in vitro model of glutamate excitotoxicity, an Agrimonia eupatoria L. extract enhanced hippocampal HT22 cell viability by free radical scavenging and oxidative stress reduction (Lee et al. 2010).

\section{Potential adverse events}

The lack of placebo-controlled clinical studies limits our knowledge on agrimony's possible adverse events. Nevertheless, the American Herbal Products Association (AHPA) considers it a class 1 drug: there is a potential for the occurrence of adverse events but these are unreported. As a photosensitive plant, Agrimonia is believed to cause different types of photodermatitis. (Grieve 1931).

\section{Substances detected in agrimony and structure-related biological activities at a glance}

Agrimonia eupatoria L. contains a large variety of biologically active substances (for details, see Table 1). It was documented that individual molecules can exert a combined, synergistic effect (Al-Snafi 2015, Bradley 1992, ESCOP 2005).

Agrimony eupatoria L.'s biologically active substances:

- polyphenols (tannins, phenolic acids, flavonoids and terpenoids),

- polysaccharides

- triterpenoids

- $\quad$ salicylic acid

- minerals, trace amounts of essential oils

- organic acids, ascorbic acid, nicotinamide complex, palmitic and stearic acids, ceryl alcohol and $0.2 \%$ of volatile acids

According to previous phytochemical analyses, agrimony dried herb contains:

- tannins (2\%) (Correia et al. 2006, Granica et al. 2015)

- flavonoids (1,2-1.4\%) (Kurkina 2011, Lee et al. 2010, Shabana et al. 2003)

- phenolic acids (2.26\%) (Granica et al. 2015, Shabana et al. 2003)

- minerals (7.3-7.5\%) (Bradley 1992)

- triterpenoids (0.6\%) (Le Men and Pourrat 1955)

- $\quad$ volatile oils (Al-Snafi 2015, Feng et al. 2013)

- $\quad$ vitamins (EMA 2015)

- $\quad$ acids (EMA 2015)

- other constituents

\section{Tannins}

Agrimonia eupatoria L. contains at least $2 \%$ of tannins. Its building block is pyrogallol $\left(\mathrm{C}_{6} \mathrm{H}_{6} \mathrm{O}_{3}, \mathrm{M}_{\mathrm{r}}\right.$ 126.1). Three to $21 \%$ of tannins are condensed tannins, in particular proanthocyanidins (procyanidin B3) (Correia et al. 2006, Cos et al. 2012). The proanthocyanidins are present mainly in the form of leuco-anthocyanins bioconverted by acid hydrolysis to cyanidin.

Tannin categories:

- hydrolysable tannins (gallotannin, agrimoniin)

- condensed tannins (proanthocyanidins)

Tannins have demonstrated antiseptic, astringent, antioxidant, anti-inflammatory, anti-mutagenic properties (Kocaçalişkan et al. 2006, Serrano et al. 2009, Sieniawska 2015).

\section{Flavonoids}

Agrimony comprises $1.2-1.4 \%$ of flavonoids, which are phenylchromen derivatives (Kurkina 2011). Of these, the therapeutically important compounds include flavanones (hesperidin), flavones (apigenin, luteolin), flavonols (kaempferol, quercetin, quercitrin, myricetin, rutin), and isoflavans.

The most important members of the flavonoid family are listed below (Bilia et al. 1993, Kurkina 2011):

- hyperoside 
- luteolin, its glucuronide isomers

- $\quad$ apigenin, its 7-O-glucoside, 7-O- $\beta$-D glucuronide

- quercetin,

- quercitrin, its 3-O-rhamnoside, rhamnoglucoside isomer, malonyl hexoside isomers

- isoquercitrin

- kaempferol, its 3-glucoside, 3-rhamnoside, 3rutenoside, 7-O- $\beta$-D glucuronide, malonyl hexoside, hexoside, kaempferide, kaempferide 3-rhamnoside

- rutin

- isovitexin

Flavonoids have a significant antioxidant, antiinflammatory, anti-allergic potential. Moreover, these compounds have been shown to exert diuretic, spasmolytic and vasodilator effects (Aslam et al. 2018, Tomko et al. 1999). Quercitrin is a quercetin glycoside shown to have higher bioavailability than quercetin (Guo and Bruno 2015). Topical application of isoquercitrin (isotrifoliin) (Bhatia et al. 2016), rutin (Almeida et al. 2012) and luteolin (Ozay et al. 2018) has proved beneficial in wound healing. Rutin has antihypertensive, anti-proliferative, antiseptic properties; it increases the efficacy of vitamin C, suppresses platelet aggregation thus preventing blood clot formation, promotes vessel wall elasticity while decreasing their fragility (Ganeshpurkar and Saluja 2017). Kaempferol and its glycosides possess antimicrobial and analgesic properties (Calderón-Montaño et al. 2011), with some of them directly inhibiting lipid peroxidation (Van Acker et al. 1996). Luteolin is a flavone reactive oxygen and nitrogen species scavenger (Xagorari et al. 2002).

\section{Phenolic acids}

Phenolic acids $(2.26 \%)$ are the most widely distributed plant non-flavonoid polyphenolic compounds (Granica et al. 2015, Shabana et al. 2003). Structurally, they are divided into hydroxybenzoic acid derivatives (benzoic, gallic, gentisic, salicylic, vanillic acids) and cinnamic acid derivatives (ferulic, caffeic, coumaric acids). They exert antioxidant activity by scavenging the hydroxyl radical and superoxide anion.

Polyphenolic compounds:

- chlorogenic acid

- caffeic acid

- $\quad$ ellagic acid

- p-hydroxybenzoic acid

- protocatechuic acid

- homoprotocatechuic acid
- $\quad$ genitisic acid

- vanillic acid

- $\quad$ salicylic acid

- p-coumaric acid

- ferulic acids

- 3-O-p-coumaroylquinic acid, 4-O-caffeoylquinic acid

- 5-O-caffeoylquinic acid

Caffeic acid, p-hydroxybenzoic acid, ellagic acid (Yuniarti et al. 2018), genitisic acid (Joshi et al. 2012), 3-O-p-coumaroylquinic acid and protocatechuic acid (Son et al. 2018) exhibit antioxidant and antiinflammatory actions (Phan et al. 2001).

Caffeic acid inhibits myeloperoxidase activity, downregulates the inflammatory mediators nitric oxide synthase, COX-2 and TNF- $\alpha$, and stimulates production of collagen polymers (Romana-Souza et al. 2018, Song et al. 2008).

Ellagic acid has demonstrated antiproliferative and antioxidant properties, and stimulates angiogenesis (Yuniarti et al. 2018).

Vanillic acid has antibacterial and antiinflammatory effects (Torzewska and Rozalski 2014).

P-coumaric acid is a hydroxy derivative of cinnamic acid, has been shown to inhibit ROS (reactive oxygen species) production (Yue et al. 2019), downregulates the growth factors VEGF (vascular endothelial growth factor) and bFGF (basic fibroblast growth factor), has antiangiogenic, anti-infective, antioxidant, acts as a free radical scavenger, protects pancreatic islets, prevents myocardial and lung injury (Kong et al. 2013) and exerts hepatoprotective and hypolipidemic effects (Shen et al. 2019).

Ferulic acid has antibacterial, antiviral, antiallergic, anti-inflammatory and antioxidant effects, inhibits melatonin production while reducing oxidative stress and thymine formation (Park et al. 2018, Zduńska et al. 2018).

Chlorogenic acid has been shown to attenuate oxidative stress. It has an anti-oxidant potential, inhibits lipid peroxidation, increases nitric oxide (NO) usage in vessels, improves endothelial function, and exerts antibacterial and anti-inflammatory actions (Suzuki et al. 2006, Tajik et al. 2017).

Rosmarinic acid has an antioxidant potential and antiviral, antibacterial and anti-allergic properties (Shekarchi et al. 2012).

Salicylic acid possesses analgesic properties, 
inhibits COX and reduces prostaglandin production while inhibiting uridin-5-diphosphoglucose (UDPG) oxidation and synthesis of mucosal polysaccharides (Lee and Spencer 1969).
Triterpenoids

Triterpenoids (triterpenoid saponins) are pentacyclic molecules synthesized from isoprene, and show anti-inflammatory, antioxidant and antimicrobial effects (Woźniak et al. 2015).

Table 1. Substances contained in agrimony

\begin{tabular}{|c|c|c|c|}
\hline Group of compounds & $\begin{array}{l}\text { Percentage } \\
\text { content }\end{array}$ & Examples & References \\
\hline Tannins & $2 \%$ & $\begin{array}{l}\text { Proanthocyanidins } \\
\text { (procyanidin B3) } \\
\text { Leuko-anthocyanin } \\
\text { Ellagitannins }\end{array}$ & $\begin{array}{l}\text { (Correia et al. 2006, } \\
\text { Granica et al. 2015) }\end{array}$ \\
\hline Flavonoids & $1.2-1.4 \%$ & $\begin{array}{l}\text { Hyperoside } \\
\text { Luteolin } \\
\text { Apigenin } \\
\text { Quercetin } \\
\text { Isoquercitrin } \\
\text { Kaempferol }\end{array}$ & $\begin{array}{l}\text { (Kurkina, 2011, Lee et } \\
\text { al. 2010, Shabana et al. } \\
\text { 2003) }\end{array}$ \\
\hline $\begin{array}{l}\text { Phenolic acids } \\
\text { (Granica et al. 2015, } \\
\text { Shabana et al. 2003) }\end{array}$ & $2.26 \%$ & $\begin{array}{l}\text { Chlorogenic acid } \\
\text { Ellagic acid } \\
\text { p-Hydroxybenzoic acid } \\
\text { Protocatechuicacid } \\
\text { Homoprotocatechuic acid } \\
\text { Genitisic acid } \\
\text { Vanillic acid } \\
\text { Salicylic acid } \\
\text { p-Coumaric acid } \\
\text { Ferulic acids } \\
\text { 3-O-p-coumaroylquinic acid, } \\
\text { 4-O-caffeoylquinic acid } \\
\text { 5-O-caffeoylquinic acid }\end{array}$ & $\begin{array}{l}\text { (Granica et al. 2015, } \\
\text { Shabana et al. 2003) }\end{array}$ \\
\hline Triterpenoids & $0.6 \%$ & $\begin{array}{l}\text { Urosolic acid } \\
\text { Euscapic acid } \\
28-\beta \text {-D-glucopyranosyl euscapic acid } \\
\text { Tormentic acid esters }\end{array}$ & $\begin{array}{l}\text { (Le Men and Pourrat } \\
\text { 1955) }\end{array}$ \\
\hline Acids & & $\begin{array}{l}\text { Palmitic acid } \\
\text { Stearic acid } \\
\text { Silicic acid }\end{array}$ & (EMA 2015) \\
\hline Volatile oils & $0.2 \%$ & $\begin{array}{l}\text { Cedrol } \\
\alpha \text {-Pinene } \\
\text { Linalool } \\
\alpha \text {-Terpineol } \\
\text { Bornyl acetate } \\
\text { Eucalyptol }\end{array}$ & $\begin{array}{l}\text { (Al-Snafi 2015, Feng } \\
\text { et al. 2013) }\end{array}$ \\
\hline Vitamins & & $\begin{array}{l}\text { Vitamin C } \\
\text { Nicotinamide complex } \\
\text { Thiamine }\end{array}$ & (EMA 2015) \\
\hline Minerals & $7.3-7.5 \%$ & Silicon dioxide & (Bradley 1992) \\
\hline
\end{tabular}


The triterpenoids most abundant in agrimony include (EMA 2015):

- urosolic acid (0.6\%) (Le Men and Pourrat 1955)

- $\quad$ euscapic acid

- 28- $\beta$-D glucopyranosyl esters of euscapic acid

- tormentic acid

\subsection{Minerals}

Agrimony is relatively rich in silica (7.3-7.9\%), potassium $(12.882 \mu \mathrm{g} / \mathrm{g})$ and sodium $(37.2 \mu \mathrm{g} / \mathrm{g})$ (Bradley 1992, EMA 2015).

\section{Vitamins}

Agrimonia eupatoria L. contains a variety of vitamins (EMA 2015):

- $\quad$ ascorbic acid (vitamin C)

- $\quad$ nicotinamid complex $(100-300 \mu \mathrm{g} / \mathrm{g})$

- thiamine $(2 \mu \mathrm{g} / \mathrm{g})$

- $\operatorname{vitamin} \mathrm{K}$

\section{Volatile oils}

Agrimony contains volatile oils $(0.2 \%)$ (Al-Snafi 2015, Feng et al. 2013). Volatile oils are a mixture of hydrocarbon terpenes, sesquiterpenes, polyterpenes and their oxygenated derivatives. Volatile oils have carminative, antibacterial, antiviral and antiinflammatory properties.

Volatile oils in agrimony:

- cedrol

- $\alpha$-pinene

- linalool

- $\alpha$-terpineol

- bornyl acetate

- eucalyptol

Cedrol has antiseptic, toning and antifungal effects and promotes extracellular matrix formation via increased ERK1/2, p38 and Akt phosphorylation (Jin et al. 2012).

$\alpha$-Pinene exerts, by inhibition of prostaglandin E1 (PGE1), anti-inflammatory and antimicrobial effects (Tümen et al. 2018)

$\alpha$-Terpineol has antiseptic, antiparasitic antiinflammatory properties, and decreases the levels of TNF- $\alpha$, GE2, and the interleukins IL-1 $\beta$, IL- 8 and IL-10
(Hart et al. 2000).

$$
\text { Eucalyptol (1,8-cineol) possesses anti- }
$$

inflammatory activity, decreases myeloperoxidase concentrations and inhibits the cytokines TNF- $\alpha$, IL-1 $\beta$ IL-4 and IL-5 (Juergens et al. 2003).

\section{Conclusions}

Agrimonia eupatoria L. is an herb with a wide range of effects. Results of experiments published to date have demonstrated its antimicrobial, antiviral, antioxidant, anti-inflammatory, hepatoprotective, neuroprotective, anti-cancer and anti-diabetic actions as well as a beneficial effect on wound healing. Besides, Agrimonia eupatoria L. exerts an immunoprotective effect, decreases the levels of pro-inflammatory cytokines while increasing those of anti-inflammatory cytokines. It has been shown to interfere with NO regulation, stimulate the expression and activity of the antioxidant enzymes superoxide dismutase, catalase and glutathione, and to scavenge free radicals. In the liver, the herb inhibits TLR-4 signaling and helps alleviate liver injury. In the intestines, its extracts inhibit $\alpha$-glucosidase and, consequently, glucose absorption. Furthermore, it has been found to exert a cytostatic effect on tumor cells without affecting normal ones. The herb's extracts inhibit thrombus formation and the intrinsic pathway. This review thus brings a summary of the biological activities of agrimony together with mounting evidence of subcellular mechanisms of action of individual compounds. Clinical trials documenting and corroborating the beneficial actions of this medicinal plant in clinical practice are lacking. However, the currently available data on Agrimonia eupatoria L. and herbs of the same genus Agrimonia represent an interesting and affordable source of bioactive compounds with a remarkable potential for therapeutic purposes.

\section{Conflict of Interest}

There is no conflict of interest.

\section{Acknowledgements}

Development of this review was funded by a SVV grant (No. 260540). 


\section{References}

AD'HIAH AH, AL-BEDERI ONH, AL-SAMMARRAE KW: Cytotoxic effects of Agrimonia eupatoria L. against cancer cell lines in vitro. J Assoc Arab Univ Basic Appl Sci 14: 87-92, 2013. https://doi.org/10.1016/j.jaubas.2013.01.003

AL-SNAFI AE: The pharmacological and therapeutic importance of Agrimonia eupatoria - a review. Asian J Pharm Sci Technol 5: 112-117, 2015.

ALMEIDA JS, BENVEGNÚ DM, BOUFLEUR N, RECKZIEGEL P, BARCELOS RCS, CORADINI K, DE CARVALHO LM, BÜRGER ME, BECK RCR: Hydrogels containing rutin intended for cutaneous administration: efficacy in wound healing in rats. Drug Dev Ind Pharm 38: 792-799, 2012. https://doi.org/10.3109/03639045.2011.628676

ASIM SA, AHMED S, NAJAM-US-SEHAR: Psoralen-ultraviolet a treatment with psoralen - ultraviolet B therapy in the treatment of psoriasis. Pakistan J Med Sci 29: 758-762, 2013. https://doi.org/10.12669/pjms.293.2622

ASLAM MS, AHMAD MS, RIAZ H, RAZA SA, HUSSAIN S, QURESHI OS, MARIA P, HAMZAH Z, JAVED O: Role of flavonoids as wound healing agent. Phytochemicals - Source of Antioxidants and Role in Disease Prevention, 2018. https://doi.org/http://dx.doi.org/10.5772/57353

BAE H, KIM H-J, SHIN M, LEE H, YIN CS, RA J, KIM J: Inhibitory effect of Agrimoniae Herba on lipopolysaccharide-induced nitric oxide and proinflammatory cytokine production in BV2 microglial cells. Neurol Res 32: 53-57, 2010. https://doi.org/10.1179/016164109x12537002794002

BHATIA N, KAUR G, SONI V, KATARIA J, DHAWAN RK: Evaluation of the wound healing potential of isoquercetin-based cream on scald burn injury in rats. Burn Trauma 4: 1-8, 2016. https://doi.org/10.1186/s41038-016-0032-1

BILIA AR, PALME E, CATALANO S, PISTELLI L, MORELLI I: Constituents and biological assay of Agrimonia eupatoria. Fitoterapia 64: 549-551, 1993.

BLAYDON DC, KELSELL DP: Defective channels lead to an impaired skin barrier. J Cell Sci 127: 4343-4350, 2014. https://doi.org/10.1242/jcs.154633

BRADLEY PR: British herbal compendium vol 1: 1992. ISBN 978-0-903032-14-8

BULAT V, SITUM M, DEDIOL I, LJUBICIĆ I, BRADIĆ L: The mechanisms of action of phototherapy in the treatment of the most common dermatoses. Coll Antropol 35: 147-151, 2011.

CALDERÓN-MONTAÑO JM, BURGOS-MORÓN E, PÉREZ-GUERRERO C, LÓPEZ-LÁZARO M: A review on the dietary flavonoid kaempferol. Mini Rev Med Chem 11: 298-344, 2011. https://doi.org/10.2174/138955711795305335

CAMERON ML: Anglo-Saxon medicine Cambridge University Press Cambridge 2006. ISBN 9780521031226

CARDOSO O, DONATO MM, LUXO C, ALMEIDA N, LIBERAL J, FIGUEIRINHA A, BATISTA MT: AntiHelicobacter pylori potential of Agrimonia eupatoria L. and Fragaria vesca. J Funct Foods 44: 299-303, 2018. https://doi.org/10.1016/i.jff.2018.03.027

CHENG X, JIN J, HU L, SHEN D, DON X, PING SAMIE MA, KNOFF J, EISINGER B, LIU ML, HUANG SM, CATERINA MJ, DEMPSEY P, MICHAEL LE, DLUGOSZ AA, ANDREWS NC, CLAPHAM DE, XU H: TRP channel regulates EGFR signaling in hair morphogenesis and skin barrier formation. Cell 141: 331-343, 2010. https://doi.org/10.1016/j.cell.2010.03.013

CHO YM, KWON JE, LEE M, LEA Y, JEON DY, KIM HJ, KANG SC: Agrimonia eupatoria L (Agrimony) Extract Alters Liver Health in Subjects with Elevated Alanine Transaminase Levels: A Controlled Randomized and Double-Blind Trial. J Med Food 21: 282-288, 2018. https://doi.org/10.1089/jmf.2017.4054

CORREIA H, GONZÁLEZ-PARAMÁS A, AMARAL MT, SANTOS-BUELGA C, BATISTA MT: Polyphenolic profile characterization of Agrimonia eupatoria L. by HPLC with different detection devices. Biomed Chromatogr 20: 88-94, 2006. https://doi.org/10.1002/bmc.533

CORREIA HS, BATISTA MT, DINIS TCP: The activity of an extract and fraction of Agrimonia eupatoria L. against reactive species. BioFactors 29: 91-104, 2007. https://doi.org/10.1002/biof.552029209

COS P, BRUYNE T, HERMANS N, APERS S, BERGHE D, VLIETINCK A: Proanthocyanidins in health care: current and new trends. Curr Med Chem 11: 1345-1359, 2012. https://doi.org/10.2174/0929867043365288 
CWIKLA C, SCHMIDT K, MATTHIAS A, BONE KM, LEHMANN R, TIRALONGO E: Investigations into the Antibacterial Activities of Phytotherapeutics against Helicobacter pylori and Campylobacter jejuni. Phyther Res 24: 649-656, 2010. https://doi.org/10.1002/ptr.2933

EDWARDS R, HARDING KG: Bacteria and wound healing. Curr Opin Infect Dis 17: 91-96, 2004. https://doi.org/10.1097/00001432-200404000-00004

EMA: Assessment report on Agrimonia eupatoria L. herba. Eur Med Agency - Comm. Herb Med Prod 44: 1-19, 2015.

ESCOP: ESCOP monographs 2nd ed supplement. Agrimoniae herba - Agrimony herb 2005.

FEI X, YUAN W, JIANG L, WANG H: Opposite effects of Agrimonia pilosa Ledeb aqueous extracts on blood coagulation function. Ann Transl Med 5: 1-9, 2017. https://doi.org/10.21037/atm.2017.03.17

FENG XL, HE YB, LIANG YZ, WANG YL, HUANG LF, XIE JW: Comparative analysis of the volatile components of Agrimonia eupatoria from leaves and roots by gas chromatography-mass spectrometry and multivariate curve resolution. J Anal Methods Chem 2013: 1-9, 2013. https://doi.org/10.1155/2013/246986

GALLAGHER AM, FLATT PR, DUFFY G, ABDEL-WAHAB YHA: The effects of traditional antidiabetic plants on in vitro glucose diffusion. Nutr Res 23: 413-424, 2003. https://doi.org/10.1016/S0271-5317(02)00533-X

GANESHPURKAR A, SALUJA AK: The pharmacological potential of rutin. Saudi Pharm J 25: 149-164, 2017. https://doi.org/10.1016/j.jsps.2016.04.025

GHAIMA KK: Antibacterial and wound healing activity of some Agrimonia eupatoria extracts. Baghdad Sci J 10: 152-160, 2013. https://doi.org/10.21123/bsj.10.1.152-160

GIACHETTI D, TADDEI I, CENNI A, TADDEI E: Diuresis from distilled water compared with that from vegetable drugs. Planta Med 55: 2-10, 1989. https://doi.org/10.1055/s-2006-961852

GRÄBER T, KLUGE H, GRANICA S, HORN G, KALBITZ J, BRANDSCH C, BREITENSTEIN A, BRÜTTING C, STANGL GI: Agrimonia procera exerts antimicrobial effects, modulates the expression of defensins and cytokines in colonocytes and increases the immune response in lipopolysaccharide-challenged piglets. BMC Vet Res 14: 1-12, 2018. https://doi.org/10.1186/s12917-018-1680-0

GRANICA S, KLUGE H, HORN G, MATKOWSKI A, KISS AK: The phytochemical investigation of Agrimonia eupatoria L. and Agrimonia procera Wallr as valid sources of Agrimoniae herba - the pharmacopoeial plant material. J Pharm Biomed Anal 114: 272-279, 2015. https://doi.org/10.1016/j.jpba.2015.05.027

GRAY AM, FLATT PR: Actions of the traditional anti-diabetic plant, Agrimony eupatoria (agrimony): effects on hyperglycaemia, cellular glucose metabolism and insulin secretion. Br J Nutr 80: 109-114, 1998. https://doi.org/10.1017/s0007114598001834

GRIEVE M: A Modern Herbal. CF Leyel London 1931.

GUO S, DIPIETRO LA: Critical review in oral biology \& medicine: Factors affecting wound healing. J Dent Res 89: 219-229, 2010. https://doi.org/10.1177/0022034509359125

GUO Y, BRUNO RS: Endogenous and exogenous mediators of quercetin bioavailability. J Nutr Biochem 26: 201-210, 2015. https://doi.org/10.1016/j.jnutbio.2014.10.008

GUPTA A, AVCI P, DAI T, HUANG Y-Y, HAMBLIN MR: Ultraviolet radiation in wound care: sterilization and stimulation. Adv Wound Care 2: 422-437, 2013. https://doi.org/10.1089/wound.2012.0366

GURITA (CIOBOTARU) LG, PAVEL AZ, POENARU R, MOACA EA, FLORESCU R, DANCIU R, DUMITRASCU C, IMBREA I, POP O: Assessment of the antioxidant effect of ethanolic extracts obtained from Agrimonia eupatoria L. filipendula ulmaria (L) maxim. and filipendula vulgaris moench collected from the estern part of Romania. Rev Chim 69: 2385-2390, 2018. https://doi.org/10.37358/rc.18.9.6539

GUZIK TJ, KORBUT R, ADAMEK-GUZIK T: Nitric oxide and superoxide in inflammation and immune regulation. J Physiol Pharmacol 54: 469-487, 2003.

HART PH, BRAND C, CARSON CF, RILEY TV, PRAGER RH, FINLAY-JONES JJ: Terpinen-4-ol, the main component of the essential oil of Melaleuca alternifolia (tea tree oil), suppresses inflammatory mediator production by activated human monocytes. Inflamm Res 49: 619-626, 2000. https://doi.org/10.1007/s000110050639

HUANG W, DENG H, JIN S, MA X, ZHA K, XIE M: The isolation, structural characterization and anti-osteosarcoma activity of a water soluble polysaccharide from Agrimonia pilosa. Carbohydr Polym 187: 19-25, 2018. https://doi.org/10.1016/j.carbpol.2018.01.047 
IMURA K, YOSHIOKA T, HIKITA I, TSUKAHARA K, HIRASAWA T, HIGASHINO K, GAHARA Y, ARIMURA A, SAKATA T: Influence of TRPV3 mutation on hair growth cycle in mice. Biochem Biophys Res Commun 363: 479-483, 2007. https://doi.org/10.1016/j.bbrc.2007.08.170

IVANOVA D, VANKOVA D, NASHAR M: Agrimonia eupatoria tea consumption in relation to markers of inflammation, oxidative status and lipid metabolism in healthy subjects. Arch Physiol Biochem 119: 32-37, 2013. https://doi.org/10.3109/13813455.2012.729844

IVANOVA DG, TASINOV O, VANKOVA D, KISELOVA-KANEVA Y: Antioxidative potential of Agrimonia eupatoria L. J Sci Technol I: 20-24, 2011.

JAHODÁŘ L: Medicinal plants in modern medicine or what Mathioli did not know yet (in Czech), 1. ed. Havlíček Brain Team 2010.

JAIN N, SHARMA PK, BANIK A, BHARDWAJ V: Applications of photosensitizer in therapy. Pharmacogn J 3: 11-17, 2011. https://doi.org/10.5530/pj.2011.22.3

JANG HH, NAM SY, KIM MJ, KIM JB, CHOI JS, KIM HR, LEE YM: Agrimonia pilosa Ledeb aqueous extract improves impaired glucose tolerance in high-fat diet-fed rats by decreasing the inflammatory response. BMC Complement Altern Med 17: 1-8, 2017. https://doi.org/10.1186/s12906-017-1949-Z

JIN MH, PARK SG, HWANG YL, LEE MH, JEONG NJ, ROH SS, LEE Y, KIM CD, LEE JH: Cedrol enhances extracellular matrix production in dermal fibroblasts in a MAPK-dependent manner. Ann Dermatol 24: 16-21, 2012. https://doi.org/10.5021/ad.2012.24.1.16

JOSHI R, GANGABHAGIRATHI R, VENU S, ADHIKARI S, MUKHERJEE T: Antioxidant activity and free radical scavenging reactions of gentisic acid: in-vitro and pulse radiolysis studies. Free Radic Res 46: 11-20, 2012. https://doi.org/10.3109/10715762.2011.633518

JUERGENS UR, DETHLEFSEN U, STEINKAMP G, GILLISSEN A, REPGES R, VETTER H: Anti-inflammatory activity of 1.8-cineol (eucalyptol) in bronchial asthma: a double-blind placebo-controlled trial. Respir Med 97: 250-256, 2003. https://doi.org/10.1053/rmed.2003.1432

JUNG CH, KIM JH, PARK SJ, KWEON DH, KIM SH, KO SG: Inhibitory effect of agrimonia pilosa Ledeb on inflammation by suppression of iNOS and ROS production. Immunol Invest 39: 159-170, 2010. https://doi.org/10.3109/08820130903501790

JUNG M, PARK M: Acetylcholinesterase inhibition by flavonoids from Agrimonia pilosa. Molecules 12: 2130-2139, 2007. https://doi.org/10.3390/12092130

KIM JJ, JIANG J, SHIM DW, KWON SC, KIM TJ, YE SK, KIM MK, SHIN YK, KOPPULA S, KANG TB, CHOI DK, LEE KH: Anti-inflammatory and anti-allergic effects of Agrimonia pilosa Ledeb extract on murine cell lines and OVA-induced airway inflammation. J Ethnopharmacol 140: 213-221, 2012. https://doi.org/10.1016/j.jep.2011.12.035

KOCAÇALIŞKAN I, TALAN I, TERZI I: Antimicrobial activity of catechol and pyrogallol as allelochemicals. Zeitschrift fur Naturforsch - Sect C J Biosci 61: 639-642, 2006. https://doi.org/10.1515/znc-2006-9-1004

KOMIAZYK M, PALCZEWSKA M, SITKIEWICZ I, PIKULA S, GROVES P: Neutralization of cholera toxin by Rosaceae family plant extracts. BMC Complement Altern Med 19: 2019. https://doi.org/10.1186/s12906-019$\underline{2540-6}$

KONG CS, JEONG CH, CHOI JS, KIM KJ, JEONG JW: Antiangiogenic effects of P-coumaric acid in human endothelial cells. Phyther Res 27: 317-323, 2013. https://doi.org/10.1002/ptr.4718

KRESÁNEK J, KREJČA J: Atlas of medicinal plants and wild berries (in Slovak), 1. ed. Osveta, Martin 1977.

KUBÍNOVÁ R, JANKOVSKÁ D, BAUEROVÁ V, KUBÍNOVÁ R, JANKOVSKÁ D, BAUEROVÁ V: Antioxidant and $\alpha$-glucosidase inhibition activities and polyphenol content of five species of agrimonia genus, Antioxidačná aktivita, inhibícia $\alpha$-glukozidázy a celkový obsah polyfenolov v piatich druhoch rodu agrimonia. Acta Fytotech Zootech 2: 38-41, 2012.

KUBÍNOVÁ R, ŠVAJDLENKA E, JANKOVSKÁ D: Anticholinesterase, antioxidant activity and phytochemical investigation into aqueous extracts from five species of agrimonia genus. Nat Prod Res 30: 1174-1177, 2016. https://doi.org/10.1080/14786419.2015.1043552 
KUCZMANNOVÁ A, BALAŽOVÁ A, RAČANSKÁ E, KAMENÍKOVÁ M, FIALOVÁ S, MAJERNÍK J, NAGY M, GÁL P, MUČAJI P: Agrimonia eupatoria L and Cynara cardunculus L. water infusions: Comparison of antidiabetic activities. Molecules 21: 1-12, 2016. https://doi.org/10.3390/molecules21050564

KURKINA AV: Medicinal plants - a method for the assay of total flavonoids. Pharm Chem J 45: 6-9, 2011.

KWON DH, KWON HY, KIM HJ, CHANG EJ, KIM MB, YOON SK, SONG EY, YOON DY, LEE YH, CHOI IS, CHOI YK: Inhibition of hepatitis B virus by an aqueous extract of Agrimonia eupatoria L. Phyther Res 19: 355-358, 2005. https://doi.org/10.1002/ptr.1689

KWON JE, LEE YG, KANG JH, BAI YF, JEONG YJ, BAEK NI, SEO YJ, KANG SC: Anti-viral activity of compounds from Agrimonia pilosa and Galla rhois extract mixture. Bioorg Chem 93: 103320, 2019. https://doi.org/10.1016/j.bioorg.2019.103320

LE MEN J, POURRAT H: Répartition de l'acide ursolique dans les feuilles de diverses Rosacées. Acide ursolique (Cinquième mémoire), in: Travaux Des Laboratoires de Matière Médicale et de Pharmacie Galénique de La Faculté de Pharmacie de Paris la Cour d'Appel 1955, p 4.

LEE KH, RHEE KH: Anti-nociceptive effect of Agrimonia eupatoria extract on a cisplatin-induced neuropathic model. African J Tradit Complement Altern Med 13: 139-144, 2016. https://doi.org/10.21010/ajtcam.v13i5.18

LEE KH, SPENCER MR: Studies on mechanism of action os salicylates V: effect of salicylic acid on enzymes involved $\begin{array}{llllll}\text { in mucopolysaccharide synthesis. J Pharm Sci } & \text { 58: 465-468, } & 1969 .\end{array}$ https://doi.org/https://doi.org/10.1002/jps.2600580416

LEE KY, HWANG L, JEONG EJ, KIM SH, KIM YC, SUNG SH: Effect of neuroprotective flavonoids of Agrimonia eupatoria on glutamate-induced oxidative injury to HT22 hippocampal cells. Biosci Biotechnol Biochem 74: 1704-1706, 2010. https://doi.org/10.1271/bbb.100200

LEE YM, KIM JB, BAE JH, LEE JS, KIM PS, JANG HH, KIM HR: Estrogen-like activity of aqueous extract from Agrimonia pilosa Ledeb in MCF-7 cells. BMC Complement Altern Med 12: 2012. https://doi.org/10.1186/1472-6882-12-260

MURUZOVIC M, MLADENOVIC K, STEFANOVIC O, ZUGIC-PETROVIC T, COMIC L: In vitro interaction between Agrimonia eupatoria L. extracts and antibiotic. Kragujev J Sci 39: 157-164, 2017. https://doi.org/10.5937/kgjsci1739157m

MURUZOVIĆ M, MLADENOVIĆ KG, STEFANOVIĆ OD, VASIĆ SM, ČOMIĆ LR: Extracts of Agrimonia eupatoria L. as sources of biologically active compounds and evaluation of their antioxidant, antimicrobial, and antibiofilm activities. J Food Drug Anal 24: 539-547, 2016. https://doi.org/10.1016/j.jfda.2016.02.007

NAM YR, KIM HJ, KIM YM, CHIN YW, BAE HS, KIM WK, NAM JH: Agrimonia pilosa leaf extract accelerates skin barrier restoration by activation of transient receptor potential vanilloid 3. J Dermatol Sci 86: 255-258, 2017. https://doi.org/10.1016/j.jdermsci.2017.03.003

NG CY, HUANG YH, CHU CF, WU TC, LIU SH: Risks for Staphylococcus aureus colonization in patients with psoriasis: a systematic review and meta-analysis. $\mathrm{Br}$ J Dermatol 177: 967-977, 2017. https://doi.org/10.1111/bjd.15366

NHO KJ, CHUN JM, KIM HK: Agrimonia pilosa ethanol extract induces apoptotic cell death in HepG2 cells. J Ethnopharmacol 138: 358-363, 2011. https://doi.org/10.1016/j.jep.2011.09.008

OKUBO Y, OKI N, TAKEDA H, AMAYA M, ITO S, OSADA M, UTSUMI M, KOGA M, KAWASHIMA H: Increased microorganisms DNA levels in peripheral blood monocytes from psoriatic patients using PCR with universal ribosomal RNA primers. J Dermatol 29: 547-555, 2002. https://doi.org/10.1111/j.1346$\underline{\text { 8138.2002.tb00179.x }}$

OPLETAL L, SKŘIVANOVÁ: Natural substances and their biological activity (in Czech). Svazek 2. Karolinum Praha 2010. ISBN 978-80-246-1801-2

OZAY Y, GUZEL S, ERDOGDU IH, YILDIRIM Z, PEHLIVANOGLU B, TURK BA, DARCAN S: Evaluation of the wound healing properties of luteolin ointments on excision and incision wound models in diabetic and nondiabetic rats. Rec Nat Prod 12: 350-366, 2018. https://doi.org/10.25135/rnp.38.17.08.135

PARK HJ, CHO JH, HONG SH, KIM DH, JUNG HY, KANG IK, CHO YJ: Whitening and anti-wrinkle activities of ferulic acid isolated from Tetragonia tetragonioides in B16F10 melanoma and CCD-986sk fibroblast cells. J Nat Med 72: 127-135, 2018. https://doi.org/10.1007/s11418-017-1120-7 
PARK JH, RA JS, KWON JE, HER YM, CHOE TH, LEE YS, SUH HJ, SHIN SY, PARK DW, KWAK HH, WOO HM, JEON H, KANG SC: Evaluation of genetic toxicity, acute and sub-chronic oral toxicity and systemic safety of Agrimonia pilosa and Rhus gall $50 \%$ ethanolic extract mixture (APRG64) in vitro and in vivo (rodent and non-rodent animal models), Toxicological Research Springer Singapore 2020. https://doi.org/10.1007/s43188-020-00042-5

PARK S, KANG S, KIM DS, MOON BR: Agrimonia pilosa Ledeb, Cinnamomum cassia Blume, and Lonicera japonica Thunb protect against cognitive dysfunction and energy and glucose dysregulation by reducing neuroinflammation and hippocampal insulin resistance in $\beta$-amyloid-infused rats. Nutr Neurosci 20: 77-88, 2017. https://doi.org/10.1080/1028415X.2015.1135572

PARK SH, SIM YB, KANG YJ, LEE JK, LIM SS, SUH HW: Effect of Agrimonia pilosa Ledeb extract on the antinociception and mechanisms in mouse. Korean J Physiol Pharmacol 16: 119-123, 2012. https://doi.org/10.4196/kjpp.2012.16.2.119

PETKOV V: Plants with hypotensive, antiatheromatous and coronarodilatationg action. Am J Chin Med VII: 197-236, 1979.

PHAN TT, WANG L, SEE P, GRAYER RJ, CHAN SY, LEE ST: Phenolic compounds of Chromolaena adorata protect cultured skin cells from oxidative damage: implication for cutaneous wound healing. Biol Pharm Bull 24: 1373-1379, 2001. https://doi.org/10.1248/bpb.24.1373

QU D, SUN W, CHEN Y, ZHOU J, LIU C: Synthesis and in vitro antineoplastic evaluation of silver nanoparticles mediated by Agrimoniae herba extract. Int J Nanomedicine 9: 1871-1882, 2014. https://doi.org/10.2147/IJN.S58732

RING J, ALOMAR A, BIEBER T, DELEURAN M, FINK-WAGNER A, GELMETTI C, GIELER U, LIPOZENCIC J, LUGER T, ORANJE AP, SCHÄFER T, SCHWENNESEN T, SEIDENARI S, SIMON D, STÄNDER S, STINGL G, SZALAI S, SZEPIETOWSKI JC, TAÏEB A, WERFEL T, WOLLENBERG A, DARSOW U: Guidelines for treatment of atopic eczema (atopic dermatitis) Part I. J Eur Acad Dermatology Venereol 26: 1045-1060, 2012. https://doi.org/10.1111/j.1468-3083.2012.04635.x

ROMANA-SOUZA B, DOS SANTOS JS, MONTE-ALTO-COSTA A: Caffeic acid phenethyl ester promotes wound healing of mice pressure ulcers affecting NF-אB, NOS2 and NRF2 expression. Life Sci 207: 158-165, 2018. https://doi.org/10.1016/j.lfs.2018.05.057

SAIER C, GOMMLICH I, HIEMANN V, BAIER S, KOCH K, HORN G, KOWALEWSKY T, BARTELT J, SEEMANN M, WÄTJEN W: Agrimonia procera Wallr. extract increases stress resistance and prolongs life span in caenorhabditis elegans via transcription factor DAF-16 (foxo orthologue). Antioxidants 7: 2018. https://doi.org/10.3390/antiox7120192

SANTOS TN, COSTA G, FERREIRA JP, LIBERAL J, FRANCISCO V, PARANHOS A, CRUZ MT, CASTELOBRANCO M, FIGUEIREDO IV, BATISTA MT: Antioxidant, anti-inflammatory, and analgesic activities of Agrimonia eupatoria L. infusion. Evidence-based Complement Altern Med 2017. https://doi.org/10.1155/2017/8309894

SERRANO J, PUUPPONEN-PIMIÄ R, DAUER A, AURA AM, SAURA-CALIXTO F: Tannins: current knowledge of food sources, intake, bioavailability and biological effects. Mol Nutr Food Res 53: 310-329, 2009. https://doi.org/10.1002/mnfr.200900039

SHABANA MH, WERGLARZ Z, GESZPRYCH A, MANSOUR R, EL-ANSAEI MA: Phenolic constituents of agrimony (Agrimonia eupatoria L.) herb. Herba Pol 49: 24-28, 2003.

SHEKARCHI M, HAJIMEHDIPOOR H, SAEIDNIA S, GOHARI AR, HAMEDANI MP: Comparative study of rosmarinic acid content in some plants of Labiatae family. Pharmacogn Mag 8: 37-41, 2012. https://doi.org/10.4103/0973-1296.93316

SHEN Y, SONG X, LI L, SUN J, JAISWAL Y, HUANG J, LIU C, YANG W, WILLIAMS L, ZHANG H, GUAN Y: Protective effects of p-coumaric acid against oxidant and hyperlipidemia-an in vitro and in vivo evaluation. Biomed Pharmacother 111: 579-587, 2019. https://doi.org/10.1016/j.biopha.2018.12.074

SHIN WJ, LEE KH, PARK MH, SEONG BL: Broad-spectrum antiviral effect of Agrimonia pilosa extract on influenza viruses. Microbiol Immunol 54: 11-19, 2010. https://doi.org/10.1111/j.1348-0421.2009.00173.X 
SIENIAWSKA E: Activities of tannins- from in vitro studies to clinical trials. Nat Prod Commun 10: 1877-1884, 2015. https://doi.org/10.1177/1934578x1501001118

SON JH, KIM S-Y, JANG HH, LEE SN, AHN KJ: Protective effect of protocatechuic acid against inflammatory stress induced in human dermal fibroblasts. Biomed Dermatology 2: 1-5, 2018. https://doi.org/10.1186/s41702-017$\underline{0018-\mathrm{Z}}$

SONG HS, PARK TW, SOHN UD, SHIN YK, CHOI BC, KIM CJ, SIM SS: The effect of caffeic acid on wound healing in skin-incised mice. Korean J Physiol Pharmacol 12: 343-347, 2008. https://doi.org/10.4196/kjpp.2008.12.6.343

SUZUKI A, YAMAMOTO N, JOKURA H, YAMAMOTO M, FUJII A, TOKIMITSU I, SAITO I: Chlorogenic acid attenuates hypertension and improves endothelial function in spontaneously hypertensive rats. J Hypertens 24 : 1065-1073, 2006. https://doi.org/10.1097/01.hjh.0000226196.67052.c0

SWANSTON-FLATT SK, DAY C, BAILEY CJ, FLATT PR: Traditional plant treatments for diabetes. Studies in normal and streptozotocin diabetic mice. Diabetologia 33: 462-464, 1990.

TAJIK N, TAJIK M, MACK I, ENCK P: The potential effects of chlorogenic acid, the main phenolic components in coffee, on health: a comprehensive review of the literature. Eur J Nutr 17: 2215-2244, 2017. https://doi.org/10.1007/s00394-017-1379-1

TOMI NS, KRÄNKE B, ABERER E: Staphylococcal toxins in patients with psoriasis, atopic dermatitis, and erythroderma, and in healthy control subjects. J Am Acad Dermatol 53: 67-72, 2005. https://doi.org/10.1016/j.jaad.2005.02.034

TOMKO J, KRESÁNEK J, HUBÍK J, SUCHÝ V, FELKLOVÁ M, SIKYTA B, LIBICKÝ A: Farmakognózia (in Slovak). Osveta Bratislava 1999.

TORZEWSKA A, ROZALSKI A: Inhibition of crystallization caused by Proteus mirabilis during the development of infectious urolithiasis by various phenolic substances. Microbiol Res 169: 579-584, 2014. https://doi.org/10.1016/j.micres.2013.09.020

TRIPATHI N, GOEL B, BHARDWAJ N, SAHU B, KUMAR H, JAIN SK: Virtual screening and molecular simulation study of natural products database for lead identification of novel coronavirus main protease inhibitors. J Biomol Struct Dyn 0: 1-13, 2020. https://doi.org/10.1080/07391102.2020.1848630

TSIRIGOTIS-MANIECKA M, PAWLACZYK-GRAJA I, ZIEWIECKI R, BALICKI S, MATULOVÁ M, CAPEK P, CZECHOWSKI F, GANCARZ R: The polyphenolic-polysaccharide complex of Agrimonia eupatoria L as an indirect thrombin inhibitor - isolation and chemical characterization. Int J Biol Macromol 125: 124-132, 2019. https://doi.org/10.1016/j.ijbiomac.2018.12.017

TÜMEN İ, AKKOL E.K, TAŞTAN H, SÜNTAR I, KURTCA M: Research on the antioxidant, wound healing, and anti-inflammatory activities and the phytochemical composition of maritime pine (Pinus pinaster Ait). J Ethnopharmacol 211: 235-246, 2018. https://doi.org/10.1016/j.jep.2017.09.009

TUPEC M, HÝSKOVÁ V, BĚLONOŽNÍKOVÁ K, HRANÍČEK J, ČERVENÝ V, RYŠLAVÁ H: Characterization of some potential medicinal plants from Central Europe by their antioxidant capacity and the presence of metal elements. Food Biosci 20: 43-50, 2017. https://doi.org/10.1016/j.fbio.2017.08.001

VAN ACKER SABE, VAN DEN BERG DJ, TROMP MNJL, GRIFFIOEN DH, VAN BENNEKOM WP, VAN DER VIJGH WJF, BAST A: Structural aspects of antioxidant activity of flavonoids. Free Radic Biol Med 20: 331-342, 1996. https://doi.org/10.1016/0891-5849(95)02047-0

VENSKUTONIS PR, ŠKEMAITE M, RAGAŽINSKIENE O: Radical scavenging capacity of Agrimonia eupatoria and Agrimonia procera. Fitoterapia 78: 166-168, 2007. https://doi.org/10.1016/j.fitote.2006.10.002

VOIGHTS LE: Anglo-Saxon plant remedies and the Anglo-Saxons. Hist Sci Soc 70: 250-268, 1979.

WATKINS F, PENDRY B, SANCHEZ-MEDINA A, CORCORAN O: Antimicrobial assays of three native British plants used in Anglo-Saxon medicine for wound healing formulations in 10th century England. J Ethnopharmacol 144: 408-415, 2012. https://doi.org/10.1016/j.jep.2012.09.031

WOŹNIAK $Ł$, SKĄPSKA S, MARSZAŁEK K: Ursolic acid - a pentacyclic triterpenoid with a wide spectrum of pharmacological activities. Molecules 20: 20614-20641, 2015. https://doi.org/10.3390/molecules201119721

XAGORARI A, ROUSSOS C, PAPAPETROPOULOS A: Inhibition of LPS-stimulated pathways in macrophages by the flavonoid luteolin. Br J Pharmacol 136: 1058-1064, 2002. https://doi.org/10.1038/sj.bjp.0704803 
YOON SJ, KOH EJ, KIM CS, ZEE OP, KWAK JH, JEONG WJ, KIM JH, LEE SM: Agrimonia eupatoria protects against chronic ethanol-induced liver injury in rats. Food Chem Toxicol 50: 2335-2341, 2012. https://doi.org/10.1016/j.fct.2012.04.005

YUE Y, SHEN P, XU Y, PARK Y: p-Coumaric acid improves oxidative and osmosis stress responses in Caenorhabditis elegans. J Sci Food Agric 99: 1190-1197, 2019. https://doi.org/10.1002/jsfa.9288

YUNIARTI WM, PRIMARIZKY H, LUKISWANTO BS: The activity of pomegranate extract standardized $40 \%$ ellagic acid during the healing process of incision wounds in albino rats (Rattus norvegicus). Vet World 11: 321-326, 2018. https://doi.org/10.14202/vetworld.2018.321-326

ZDUŃSKA K, DANA A, KOLODZIEJCZAK A, ROTSZTEJN H: Antioxidant properties of ferulic acid and its possible application. Skin Pharmacol Physiol 31: 332-336, 2018. https://doi.org/10.1159/000491755

ZHU L, CHEN J, TAN J, LIU X, WANG B: Flavonoids from Agrimonia pilosa Ledeb: Free radical scavenging and DNA oxidative damage protection activities and analysis of bioactivity-structure relationship based on molecular and electronic structures. Molecules 22: 1-11, 2017. https://doi.org/10.3390/molecules22030195 